\title{
The Soul-Body Union in the Summa Halensis
}

\begin{abstract}
The author of the first part of book II of the Summa Halensis - perhaps Alexander of Hales himself - was among the partisans of the plurality of forms. The aim of this paper is to examine the character of Alexander's hylomorphism, his philosophical strategies, sources, and motivations. It is argued that the Summa combines a wide range of philosophical and theological sources in order to build a non-Aristotelian anthropological vision, which is part of a broader metaphysical picture. The Aristotelian conception of the human being from the De anima, which makes the soul the first act or the form of the organic body, is rejected on the grounds of three basic assumptions: no form can move its own matter; the forms in the most proper sense are principles of homoeomerous substances, such as fire or gold; the human being is composed according to the principle of continuous proportion (analogia syneches), which rules out any direct union of elements that have nothing in common. The matter and the rational soul are such disparate elements, while the form-matter relation is direct.
\end{abstract}

As soon as the idea of a hylomorphic compound made its way into universities and became the basic conceptual pattern in physics, metaphysics, and even in some areas of theology, the controversy around the plurality of forms emerged. ${ }^{1}$ The problem was general and concerned the whole created world, but was discussed mainly with reference to human beings. During the first half of the 13th century, most theologians maintained that the human organism was determined by more than one substantial form. There were many variants of the pluralist position, but all of them were somehow related to the common view that the human soul was a complete, spiritual substance, united to a particular body which had its own autonomy of some kind. The author of the prima secundae of the Summa Halensis - perhaps Alexander of Hales himself ${ }^{2}$ - was among the partisans of the plurality of forms. Like his predecessors and contemporaries, he benefited from a wide range of philosophical and theological sources and combined them in order to build his vision of

1 For a survey of the debate on the plurality of forms, see for example Daniel A. Callus, 'Forms, Unicity and Plurality of,' in New Catholic Encyclopedia, vol. 5, 2nd ed. (Detroit: Thomson/Gale; Washington D.C.: Catholic University of America, 2003), pp. 816-19. An excellent study of the early 13th-century discussion can be found in Roberto Zavalloni, Richard de Mediavilla et la controverse sur la pluralité des forms (Louvain: Éditions de l'Institut supérieur de philosophie, 1951), pp. 383-436.

2 On the problem of the authorship of the Summa Halensis, see above all Victorin Doucet, 'The History of the Problem of the Authenticity of the Summa,' Franciscan Studies 7 (1947), pp. 274-312 (on book II, see pp. 296-310). The main part of book II was composed while Alexander was still alive, i.e. before 1245, under the strong influence of John of La Rochelle. 
the human being. ${ }^{3}$ Unsurprisingly, then, his standpoint has often been considered eclectic from a Thomistic perspective. More disputable is the tendency to accuse the so-called eclectic Aristotelianism of being philosophically unsound and superficial. In this paper, I will try to avoid this prejudice in examining the character of Alexander's hylomorphism, his philosophical strategies, sources, and motivations. My aim is to show that the Summa Halensis offers a mature and well-thought-out account of the human composite, and this account is part of a broader metaphysical picture.

\section{The Definition of the Soul}

The basic anthropological position of the Summa Halensis is revealed by the way in which the Aristotelian theory of the soul is treated in the chapter where various definitions of the soul are discussed. The attitude of the author of that chapter becomes evident in the context of other writings. In the first half of the 13th century, it was not unusual for Latin masters to quote Aristotle's definition of the soul. Roland of Cremona, ${ }^{4}$ Hugh of St Cher, ${ }^{5}$ William of Auvergne, ${ }^{6}$ John of La Rochelle ${ }^{7}$ all included the Peri psyches formula in their lists of definitions, among other, more dualistic descriptions. For each of these authors, the soul is both a form and a substance, although the words 'form' and 'first act' are used less frequently than other terms: those who followed the Arabic tradition used the term 'perfectio'; ${ }^{8}$ those who preferred to stick to the Latin translation by Jacob of Venice, spoke of entelechy. ${ }^{9}$

There was a growing interest in Aristotle's psychology in the thirties and in the forties, that is to say at the time when the second book of the Summa Halensis was written. However, at least in one aspect, the author of this book seems quite resistant

3 On the Arabic and Jewish origins of the theory of the plurality of forms, see Magdalena Bieniak, The Soul-Body Problem at Paris, ca. 1200-1250: Hugh of St-Cher and His Contemporaries (Leuven: Leuven University Press, 2010), pp. 119-30.

4 Roland of Cremona, Summa, MS Paris, Bibl. Mazarine, 795, f. 34va, in Charles R. Hess, 'Roland of Cremona's Place in the Current of Thought,' Angelicum 45:4 (1968), pp. 429-77, on p. 440; Dag Nikolaus Hasse, Avicenna's De anima in the Latin West: The Formation of a Peripatetic Philosophy of the Soul 1160-1300 (London: The Warburg Institute, 2000), pp. 36-42.

5 Hugh of St Cher, De anima, ed. Magdalena Bieniak, in 'Una questione disputata di Ugo di St-Cher sull'anima. Edizione e studio dottrinale,' Studia Antyczne i Mediewistyczne 37 (2004), pp. 127-84, on p. 169.

6 William of Auvergne, Tractatus de anima, ed. Blaise Le Feron, in Opera omnia: Supplementum, eds.

F. Hotot and Blaise Le Feron (Orléans-Paris, 1674, repr. Frankfurt a.M., 1963), p. 65.

7 John of La Rochelle, Summa de anima, ed. Jacques-Guy Bougerol (Paris: J. Vrin, 1995), p. 53.

8 See Meryem Sebti, Avicenne: L'âme humaine (Paris: Presses Universitaires de France, 2000), pp. 16-17; Bieniak, The Soul-Body Problem, pp. 13-16.

9 Aristotle, De anima, 2.1 (412a 20 -21), translatio vetus, ed. Manuel Alonso, in Peter of Spain, Obras fillosoficas, vol. 3 (Madrid: Consejo Superior de Investigaciones Cientificas, 1952), p. 188. See also Bieniak, 'Una questione disputata,' pp. 155-56, n. 100. 
to the Aristotelian fashion. The chapter on the definition of the soul - Quid sit anima secundum definitionem - does not include the Aristotelian definition. The author of the Summa knew Aristotle's libri naturales very well, as can be seen from his numerous references. Moreover, he calls the human soul 'the perfection of the body' many times. ${ }^{10}$ Surprisingly, however, in response to the question 'what is the soul?', he chooses not to include the Aristotelian account of the soul in the list of defendable definitions. ${ }^{11}$ Instead, he quotes numerous sources: a couple of Augustinian texts, the pseudo-Augustinian De spiritu et anima, the works of Seneca, Cassiodorus, and John of Damascus. On the basis of these auctoritates, the author of the Summa concludes that the soul is a spiritual substance. ${ }^{12}$ This substance is a concrete particular (hoc aliquid) and a compound of spiritual matter and form. ${ }^{13}$

But Aristotle has a role to play in this account. In order to show that the soul is an independent substance, the Summa compares the soul-body union to the relationship between a sailor and his ship, a metaphor that Aristotle himself found problematic. ${ }^{14}$ Moreover, it is vigorously argued that the soul is not a substantial form or act, and the basis for the argumentation is found in Aristotle's Physics.

According to the Summa, someone who considers the soul as the first act of an organic body has to admit that the soul is nothing more than a substantial form. This would mean that the whole act of the soul is exhausted in its matter and that the soul cannot perform any other act than that of being the act of the body.$^{15}$ Within the Peripatetic framework, this inference seems strange, because Aristotle makes a distinction between the first act and the second act: ${ }^{16}$ the first act of the body - i.e. the soul - is also responsible for all the second acts of life, such as growth, nutrition, or sense perception. Yet for Aristotle, the second acts are movements of the hylomorphic whole, i.e. of the living organism, not of the soul alone. In my opinion, this is the part of the hylomorphic theory that the author of the Summa Halensis rejects. According to the Summa, the only author and subject of bodily movements is the soul. In order to prove this standpoint, the Summa turns to Aristotle's theory of movement. In Physics, Aristotle wrote:

Of things to which the motion is essential, some derive their motion from themselves, others from something else: and in some cases their motion is natural, in others violent and unnatural.

10 Alexander of Hales, Doctoris irrefragabilis Alexandri de Hales Ordinis minorum Summa theologica (SH), 4 vols (Quaracchi: Collegium S. Bonaventurae, 1924-48), II, In2, Tr2, Q1, C5, pp. 151b, 152b; ibid., In4, Tr1, S1, Q2, Ti2, C1, p. 399a; ibid., In4, Tr1, S1, Q3, Ti1, C2, p. 404b; ibid., In4, Tr1, S1, Q3, Ti2, C1, pp. 418b-22b and C2, p. 423b; ibid., In4, Tr2, S2, Q1, Ti1, M3, C1, pp. 579a-80b.

11 In this and many other respects the Summa Halensis follows Philip the Chancellor's Summa de bono.

12 See SH II, In4, Tr1, S1, Q1, C2, pp. 384b-86a.

13 SH II, In4, Tr1, S1, Q2, Ti2, C1, p. 399a-b.

14 SH II, In4, Tr1, S1, Q1, C2, p. 386a; Aristotle, De anima, 2.1 (413a 9).

15 SH II, In4, Tr1, S1, Q1, C2, pp. 385b-86a.

16 Aristotle, De anima, 2.1 (413a 8-9). 
(...) The animal as a whole moves itself naturally: but the body of the animal may be in motion unnaturally as well as naturally: it depends upon the kind of motion that it may chance to be suffering and the kind of element of which it is composed. And the motion of things that derive their motion from something else is in some cases natural, in others unnatural: e. g. upward motion of earthy things and downward motion of fire are unnatural. Moreover the parts of animals are often in motion in an unnatural way, their positions and the character of the motion being abnormal. The fact that a thing that is in motion derives its motion from something is most evident in things that are in motion unnaturally, because in such cases it is clear that the motion is derived from something other than the thing itself. ${ }^{17}$

Drawing on Aristotle, the Summa offers the following reasoning: some movements are natural, others are contrary to nature. The natural movements - as Aristotle claims - are: for fire to rise, for earthy things to fall, and similar. The parts of a plant, for example, are weighty, earthy things. Their natural movement would be to go down, but some of them - like leaves or plant sap - move upward. The movement of leaves and sap is, therefore, not a natural movement. ${ }^{18}$ Aristotle admits that parts of living organisms may move in an unnatural way, and the unnatural motion is the best proof that an object is moved by something else. The body movements are the best proof that the body is moved by something different than itself. In the absence of an external force applied on the body, the bodily movements demonstrate that the body is moved by its soul. Consequently, the soul and the body are two different substances, even in the plants, and the demonstration of this can be found in Aristotle himself.

The soul has two basic functions related to its body: it is the principle of movement and the principle of life. The two kinds of operation are, of course, strictly related, because a living organism is moved by a kind of motion associated with life, which - as we have seen - has to be distinguished from natural movements, such as the upward movement of fire. The Summa Halensis uses the distinction between mov-

17 Aristotle, Physics, 8.4 (254b 12-25), ed. Jonathan Barnes, Complete Works of Aristotle, trans. Robert P. Hardie and Russell K. Gaye, vol. 1 (Princeton: Princeton University Press, 1984), p. 425. 18 SH II, In4, Tr1, S1, Q1, C2, pp. 386b-87a: 'Ad secundum dicendum quod in hoc discernitur vitam habens a non vivente, quia motus vitalis est in contrarium motui naturae. Videmus enim quod secundum motum naturae grave fertur deorsum et leve sursum, secundum motum vero nutrimenti grave fertur sursum, sicut apparet in plantis, et quod igneum est, ut cholera, fertur deorsum in animalibus, cum nutritur simile simili. (...) Ergo differentia est inter esse vitale et naturale, et ideo <anima> dicitur "propria substantia sui corporis vivificatrix."' ['A living being can be distinguished from something inanimate by the fact that the motion associated with life is contrary to the motion of nature. For we see that, in the movements of nature, heavy things go down, and light things go up, while in the movements of nutrition heavy things move upwards, as can be seen in plants, and the things that are fire-like, such as the bile, move downwards in animals, since like is nourished by like. (...) Hence there is a difference between a biological being and a natural being, and so the soul is called "a proper substance that vivifies its body."'] 
ing and vivifying mainly in order to explain the difference between the rational soul and the angel: an angel can assume and move a body, but it cannot give life to it. ${ }^{19}$

One feature may seem particularly striking in the Summa's rebuttal of the Peri psyches definition. In order to prove that the soul's essence is not limited to being the act of a body, it focuses on physics and on the movements of living organisms. In the chapter on the definition of the soul, it is not even mentioned that, according to Aristotle, the intellectual activity of the soul may be performed without an organ, even though the presence of such power would prove that the soul is something more than an act of body parts. Apparently, the case of intellect is not essential to the point that is being made. Let us then investigate the philosophical basis of the Summa's position.

\section{Nature and Movement}

In order to understand why the author of the Summa claims that the soul cannot be considered a form, it is useful to determine how he describes the nature of the body. The chapter on the difference between the soul and an angel contains a brief explanation of what is intended by 'natural being'. When something is considered in its natural existence, it is studied with reference to the bodies that are capable of movement. ${ }^{20}$ The soul is the principle of the life of the organism. Consequently, in order to investigate the natural being of the soul, one has to examine the motion of the human body. However, while the movements of the living body tell us a lot about the soul's nature, paradoxically, they do not tell us much about the body itself. The reason can be found again in Aristotle's Physics: 'nature is a source or cause of being moved and of being at rest in that to which it belongs primarily, in virtue of itself and not in virtue of a concomitant attribute. ${ }^{21}$ Since any movement associated with life (motus vitalis) is caused by something other than the body, namely by the soul, the Summa concludes that no movement associated with life is natural for the body.

However, any natural substance has its own natural kind of movement, and the human body is no exception. The organism is composed of flesh, blood, bones, etc. Each of these materials has its natural kind of movement; for example, blood has a natural movement similar to water, and bones have a natural movement similar to earth. This means that each kind of matter making up the body has its own nature or essence, and each of these ingredients has its own formal principle. The form itself never moves the matter of which it is the form (forma non movet suam materiam lo-

19 See SH II, In4, Tr1, S1, Q1, C2, p. 385b.

20 SH II, In2, Tr2, Q1, C5, p. 150b: 'Quantum ad esse naturale, in quo fit consideratio corporum mobilium et eorum quae ordinantur ad illa.' ['As for the natural being, we consider moving bodies and the items assigned to them.']

21 Aristotle, Physics, 2.1 (192b 20-22), p. 329. 
caliter). The role of the act is different: it makes the matter what it is, namely, the form is responsible for the actual being of the matter and for nothing more. ${ }^{22}$ The natural movement of any substance is possible thanks to its particular form, but the form does not move. Indeed, in order to cause a natural movement of something heavy, it is necessary for example to remove an obstacle or to apply some kind of force (a removente prohibens movetur et perducente ad suum locum). Even the form of fire does not move its own matter, as Alexander explicitly states (igneitas enim non movet materiam cuius est actus). We get the false impression that the form of fire moves its matter because the fire acts on the matter of the air and moves it by actualizing its potency. ${ }^{23}$

To summarize, the Summa Halensis refuses to define the soul as the first act of a body, because the only function of any act or form is to make matter what it is, namely, to confer a specific nature on matter, and not to move it. Since the soul is the principle of bodily movements, it cannot be the act of the body.

\section{Homoeomerous Substances and Living Bodies}

Properly speaking, the soul is not a form. However, in some sense the soul can be considered a kind of form or perfection. In order to explain the difference between a proper form and the soul, Alexander presents a hierarchy, in which the lowest and the most basic position is determined by what we could call the homoeomerous

22 See SH II, In4, Tr1, S1, Q2, Ti2, C1, p. 399a: 'Eodem modo forma non movet suam materiam localiter, quia non est quid actu praeter suam materiam; anima vero movet ipsum corpus quod est perfectum ab ea, et ideo non dicitur tantum forma, sed in se substantia.' ['In the same way, the form does not move its matter with regard to place, because it is something in act only in relation to its matter, whereas the soul moves the same body to which it gives perfection, hence it is not only called a form but also a substance in its own right.']; ibid., p. 399b: 'Ad quintum dicendum quod non est simile de forma et anima: forma enim, praeter hoc quod est materiae forma, non habet aliquam actualitatem; sed anima praeter hoc quod est anima, habet virtutem quamdam secundum quam dicitur habere compositionem propriam, cui respondet agere et pati, etiam cum est separata.' ['There is a difference between the form and the soul: the form does not have any actuality apart from being a form of some matter, while the soul not only is a form of some matter but also has some excellence by virtue of which it is said to be a compound in its own right, acting and being acted upon, even in its separate state.']

23 SH II, In4, Tr1, S1, Q1, C2, p. 386a: 'Et hoc patet per exemplum: igneitas enim non movet materiam cuius est actus, sed materiam aeris, ut extrahat in actu quod fuit in potentia; eodem modo ponderosum quod movetur, a removente prohibens movetur et perducente ad suum locum. Restat ergo: cum anima per se moveat corpus, erit aliquid praeter hoc quod est forma sive actus corporis; ergo erit substantia simpliciter.' ['The following example makes it clear: the form of fire does not move the matter of which it is an act, but moves the matter of the air, making actual what has been in potency. By the same token, a weighty thing in motion is moved by something that removes an obstacle and by something that leads it to its place. Consequently, given that the soul itself moves the body, the soul is something more than a form or an act of the body, hence it is simply a substance.'] 
forms. But before taking a closer look at this theory, let me make a short general remark.

A typical scholastic summa, commentary, or collection of questions covers many topics and addresses a great number of particular problems. In such vast works, it is quite normal to find slight shifts in opinions from one topic to another. These differences do not necessarily derive from the time lapse between the composition of different questions or chapters, or from a difference in authorship. The adopted line of argumentation often depends on the currently discussed issue. Each question had its own autonomous tradition, in which a standard set of auctoritates and some argumentative strategies were transmitted from one master to another. Moreover, each issue required a different approach because of the doctrinal limits imposed on each discussion. It is then no surprise that the anthropological account offered in the second book of Summa Halensis assumes a different tone depending on the problem at stake. Hence, when speaking of the definition of the soul, Alexander vividly refuses to call the soul an act, a form or even a perfectio. However, when he examines the difference between the soul and the angel or the relationship between the soul and the body, the terms 'perfectio' and 'form' turn out to be quite useful. ${ }^{24}$

Another way of saying that the soul is the principle of life is to call it a formal perfection of the body (perfectio formalis). ${ }^{25}$ Yet this label must be qualified. First, neither the essence of the body nor the essence of the soul needs to be perfected or completed. The soul is a spiritual substance, perfect in its own spiritual nature. It is naturally capable of union (unibilis), but not incomplete. By the same token, the body is a finished corporeal substance, ready for union. It needs the soul in order to live and in order to maintain its shape and qualities, since without a soul the body cannot endure; however, the nature or the essence of the body is ready before the soul arrives. The soul-body union is a natural union of two substances. The soul is called a perfectio, because a living organism is something more noble and higher than a body without a soul, not because without a soul the body is less corporeal or lacks its natural organs. ${ }^{26}$

Second, the word perfectio does not describe the soul's essence but its function in relation to the body: the spirit is considered in itself, the soul in relation to the body (de spiritu est consideratio absolute, de anima respective). ${ }^{27}$ The essence or the definition of the soul is to be a spirit. The soul is an act or a perfection, but

24 See above, n. 10.

25 SH II, In4, Tr1, S1, Q3, Ti2, C1, p. 420a: 'Ad quod dicendum quod anima rationalis coniungitur suo corpori ut motor mobili et ut perfectio formalis suo perfectibili.' ['The soul is united to its body like a mover to what is moved and like the formal perfection to what is perfected.']

26 See SH II, In4, Tr1, S1, Q3, Ti2, C1, p. 419a.

27 SH II, In2, Tr2, Q1, C5, p. 149a. See also ibid., p. 151b: 'Licet sit considerare substantiam animae in se per modum spiritus, nihilominus tamen in esse naturali est "perfectio corporis organici." ['Although one should regard the very substance of the soul as a spirit, nevertheless, with regard to its natural being, the soul is "the perfection of an organic body."'] 
only with reference to the natural world, namely in its relationship to a corporeal substance that is capable of movement. This notion is reminiscent of the famous Avicennian principle, the so-called double consideration of the soul, according to which 'the soul has two faces. ${ }^{28}$ There is, however, an important difference. Avicenna maintains that the soul's capacity for union with a particular body is an accidental feature of the soul. By contrast, Alexander of Hales, just like many other theologians of his time, claims that this aptitude for unity (unibilitas) is an essential feature. Why then does he refuse to accept the Aristotelian definition of the soul? Clearly, Alexander considered this definition reductionist: the soul is not the capacity for union but has the capacity for union. Moreover, it seems that what is intended by the 'essential capacity for union' is that the soul joins the body directly with its essence, and not, for example, through the mediation of some of its potencies. Nevertheless, as will be seen below, the soul needs some media in order to operate.

Finally, the reluctance to call the soul a form or perfection depends on a fundamental principle which is repeatedly stated in book II of the Summa Halensis. The position of this rule is significant: it can usually be found at the beginning of the solutions to the discussed problems. Moreover, the principle is not subject to modification depending on the context. The rule is as follows. There are two basic kinds of forms. The first kind - the form properly speaking - is the form closest to matter. It is the principle of the homoeomers. Such substances share all their properties with all their parts: for instance, the properties of fire or gold are the same regardless of whether we choose to consider the bulk of it, or a tiny part of a greater mass. The same rule is also expressed in terms of predicability: 'any portion of fire can be called fire.' Thus the 'material forms' act in the same way upon the whole substances and upon their parts. By contrast, the forms of the second kind act upon the matter in such a way that none of the parts are called by the same name as the whole. No part of an animal is called 'an animal' (even though some parts are sentient). ${ }^{29}$ This is why the Summa claims that the soul is a kind of form that is distant from matter: the soul gives perfection to the whole in a different manner than to its parts.

The distinction between the forms of like-parted substances and the superior forms is certainly not an invention of the Summa Halensis. Very similar accounts can be found in Philip the Chancellor's Summa de bono ${ }^{30}$ and in the Summa de anima by John of La Rochelle. ${ }^{31}$ The idea might have come from De generatione et corruptione, where Aristotle argues that every living body is composed of anhomoeo-

28 Avicenna, Liber de anima seu sextus de naturalibus, 1.1, ed. Simone van Riet (Leiden: Brill, 1972), 1.1, pp. 26-27. On the medieval reception of this theory, see above all Massimiliano Lenzi, Anima, forma e sostanza: filosofia e teologia nel dibattito antropologico del XIII secolo (Spoleto: CISAM, 2011). 29 See SH II, In4, Tr1, S1, Q1, C2, p. 386a and ibid., In4, Tr2, S2, Q1, Ti1, M3, C1, p. 579a-b. 30 Philip the Chancellor, Summa de bono, vol. 1, ed. Nicolai Wicki (Berne: Francke, 1985), pp. $288-89$.

31 John of La Rochelle, Summa de anima, 1.42, pp. 132-33. 
merous parts, each of which is composed of homoeomers, such as flesh and bone. Moreover, Aristotle claims that

the difference between the matter and the form is clearer (in the case of anhomoeomers, such as hand or head) than in the case of flesh and the homoeomers. This is why we would be more inclined to think of a dead man's flesh and bone as still existing than his hand and arm. ${ }^{32}$

This may seem not far from saying that the forms of like-parted substances are closer to the matter than the forms of complex bodies. Yet the basic distinction between the two kinds of forms does not exhaust the issue of the ontological structure of the living beings. The rational soul differs not only from the material forms, but also from the sensitive soul and the vegetative soul. The formal perfections are ordered in an ontologically founded hierarchy, which again brings us to the theory of multiple substantial forms.

\section{Analogia Syneches, or the Principle of Continuous Proportion}

Among all the formal principles, the material forms and the rational soul occupy the extreme positions. Both constitute the human being at some level. In order to think of the human being as one substance, it is necessary to link these extremes by some suitable media. This urge lies at the heart of medieval Neoplatonism and is among the basic metaphysical principles used in the Summa Halensis. It is the rule of continuous proportion - analogia syneches - made explicit by Calcidius in his Commentary on Timaeus. ${ }^{33}$ Calcidius explains how the body of the world maintains its unity despite the fact that it is composed of opposite elements, such as fire and earth, which have nothing in common. These elements are linked through media in such a way that the neighbouring elements share at least one common quality, creating a chain of partly similar and partly different components.

The same pattern is present in many 13th-century anthropological accounts, including the Summa Halensis. ${ }^{34}$ Between the material forms and the rational soul there are two formal media. The vegetative perfection belongs to the second class of forms, namely to the forms of uneven bodies, because not all the parts - or perhaps no part - of a plant can be called 'a plant'. Nevertheless, the vegetative perfection is to some extent similar to the forms of homoeomerous bodies, because it gives

32 Aristotle, De generatione et corruptione, 1.5 (321b 28-33), trans. Christopher F.J. Williams (Oxford: Clarendon Press, 1982), p. 19.

33 Calcidius, Commentarius in Timaeum, 18, ed. Jan H. Waszink (Turnhout: Brepols, 1962), p. 68. See Irene Caiazzo, 'Harmonie et mathématique dans le cosmos du XII ${ }^{e}$ siècle,' Micrologus 25 (2017), 121-47, on pp. 134-35.

34 For more on the union per media, see Bieniak, The Soul-Body Problem, pp. 119-36. 
life to each part of the organism. The vegetative form is closer to the matter than the sensitive form, since the latter is the perfection of the whole animal, but not of each of its parts. In fact, not all the organs of an animal are capable of sense perception. Finally, the rational soul, the furthest from matter, is the perfection of the whole organism, but of none of the parts, because the intellect has no proper organ. ${ }^{35}$

What Alexander implies in this account is that the hylomorphic union properly speaking is the union between the material form and matter. The union between the rational soul and the human body somewhat resembles the hylomorphic union but also differs from it in some key respects. In the hylomorphic union, the form is nothing but the act of matter; its being is exhausted in this function. The rational soul is a concrete particular (hoc aliquid) and has many acts other than conferring nature and shape on the matter. Furthermore, the rational soul is not the form of prime matter, but of an organic body, which is complete and ready for union thanks to its own form, the forma corporalis - a well-known Avicennian concept. ${ }^{36}$

As already mentioned, the soul-body union is supposed to be direct and essential. Nevertheless, the Summa Halensis claims, on the one hand, that the body has to be prepared for the union before the soul arrives; on the other hand, it affirms that the soul operates in the body through a number of media on the part of the soul and on the part of the body. On the soul's part, the organs are activated through the vegetative and the sensitive powers. Yet it is difficult to see how it is possible to claim at the same time that the soul operates in the body through its potencies and that the union is direct and essential. Perhaps it could be useful to appeal to the Aristotelian metaphor used in the Summa Halensis. The soul is like a sailor on a ship. One can say that the sailor navigates per media of his hands and legs, and still claim that his union with the ship is direct and essential, because the whole sailor is present on board. By the same token, the soul animates the body through the vegetative and sensitive powers but is directly united to the body.

However, using the sailor parallel involves a difficulty. The vegetative and sensitive potencies are not parts of the soul strictly speaking, because only corporeal beings can truly be divided, while the soul is incorporeal. Yet someone who introduces soul-based media between the rational soul and the body suggests that the soul can be divided into parts. The Summa de bono, to which the Summa Halensis is greatly indebted, supported a similar theory of media and claimed that the human soul was composed of three substances. ${ }^{37}$ The Summa Halensis claims that the soul con-

35 A long and detailed exposition of this theory can be found in SH II, In4, Tr1, S1, Q3, Ti2, C1, p. $422 \mathrm{a}-\mathrm{b}$.

36 SH II, In4, Tr1, S1, Q3, Ti2, C1, p. 422b. On the form of 'corporeity', see Avicenna, Liber de Philosophia Prima sive Scientia Divina, 2.2, ed. Simone van Riet, 3 vols (Leiden: Brill, 1977), pp. 78-79; Sebti, Avicenne, pp. 22-23. The concept can be found also in Philip the Chancellor's Summa de bono, vol. 1, p. 284.

37 See Summa de bono, vol. 1, pp. 233-34. A study of Philip's theory can be found in Zavalloni, Richard de Mediavilla, pp. 397-98, 407-9, and in Bieniak, The Soul-Body Problem, pp. 119-30. 
sists of only one indivisible substance but maintains the theory of operational media at the same time. ${ }^{38}$

The human soul combines all the forms of a living being qua living: is has the vegetative, the sensitive, and the rational powers, all embedded in one substance. One human being has only one soul, but it does not mean that it has only one form. The human body is, in fact, a complex substance. Its complexity is ensured by a multitude of material and organic forms, which are held together by the forma corporalis. Finally, the existence of the body is preserved by the ultimate perfection, namely the soul.

The numerous capacities and the complexity of the human organism bear witness to the spirituality of the soul. Inspired by Ibn Gabirol's Fons vitae, Alexander affirms: 'the more a substance is free from matter, the more actions it is capable of performing. ${ }^{39}$ Moreover, in order to bring to fruition all of its capacities, the soul needs an appropriate tool, and the human body is the right one, because it is the most sophisticated among the corporeal creatures.

The multipart, hierarchical structure of the human being reflects the structure of the universe. The same principle of continuity, which governs the body of the world, governs the human organism. But the order of resemblance is from top to bottom, not the other way around. The origin of the analogy of the natural structures is God himself, who created man in his own image (Gen. 1:27). The numerous potencies of the soul reflect the multiplicity of Forms in God's mind, and the complexity of the body reflects the powerfulness of the human soul. ${ }^{40}$ The Neoplatonic metaphysics find their ultimate validation in the book of Genesis.

\footnotetext{
38 SH II, In4, Tr1, S1, Q3, Ti1, C2, p. 404b: 'Ad quod potest responderi quod una est substantia in homine habens has virtutes; unde 'anima rationalis, cum separatur, secum trahit sensum et imaginationem', sicut dicitur in libro De anima et spiritu.' ['In the human being, there is only one substance that has these powers; accordingly, 'when the rational soul is detached, it carries away the sense perception and the imagination,' as the book On the Soul and the Spirit says.']

39 SH II, In4, Tr2, S2, Q1, Ti1, M3, C1, p. 579a: 'Quanto substantia aliqua magis est immunis a materia, tanto plurium operationum est effectiva.' See Avicebron, Fons vitae, ed. Clemens Baeumker (Munich: Aschendorff, 1895), tr. 4 (n. 14), p. 243: 'Et propter hoc accidit quod una substantia est sapientior alia et perfectior, scilicet propter spissitudinem materiae et turbationem, non propter formam in se ipsa, quia scientia et cognitio ex forma est.' ['And for that reason, it happens that some substances are wiser and more perfect than others - because of the density of the matter and due to some perturbation, not by virtue of the form as such, since knowledge and cognition come from the form.'] Alexander uses the Fons vitae quite frequently and adopts Ibn Gabirol's view that the soul is composed of form and matter.
}

40 See SH II, In4, Tr2, S2, Q1, Ti1, M3, C1, p. 578b. 


\section{Conclusion}

I believe that there is enough evidence to state that Alexander is not seeking to mitigate the Peri psyches definition in order to protect the soul's immortality, but he simply rejects the Aristotelian notion of the soul for its own sake. He does this on the grounds of some well-defined philosophical principles, which include the following:

1. In a hylomorphic composite, the only function of the form is to make the respective matter what it is. In particular, a form which gives perfection to some matter cannot be the mover of that matter.

2. The forms in the first and most proper sense of the word are forms of homoeomerous substances. The soul is not a form properly speaking, because no part of an animal can be called an animal.

3. The human being is a complex, pluriform organism, which is composed according to the principle of continuous proportion. Matter and the rational soul comprise the two extremes of this composite and therefore they require media in order to operate together.

None of these principles is new. What is perhaps unique in the second book of the Summa Halensis, is the attempt to find an alternative label for the soul-body combination that would emphasize its distinctiveness. Instead of calling it a 'hylomorphic unity', Alexander retrieves a formula from Bernard of Clairvaux, who called the soulbody relation an 'inborn unity' (unitas nativa, qua anima et caro unus nascitur homo). ${ }^{41}$ Alexander's attempt was appreciated by Bonaventure, who used the same label in his Sentences Commentary in order to show the analogy between the soulbody union and the hypostatic union, both of which result in the birth of one person. ${ }^{42}$ But more importantly, the attempt to find a particular name for the soulbody relation shows how strongminded the author of the Summa Halensis was in finding a coherent and comprehensive anthropological account that could compete with the Aristotelian vision.

41 SH II, In4, Tr1, S1, Q3, Ti2, C1, p. 422a: 'Ad quod dicendum quod haec unio, quae est animae et corporis, a B. Bernardo dicitur nativa et se habet ad modum formae cum materia. Sed (...) non est ibi proprie actus materiae, sed actus naturalis corporis completi in forma naturali, quae forma dicitur forma corporalis. Sic ergo habet proprium modum unionis, et ideo vocat B. Bernardus istam unionem proprio nomine unitatem nativam.' ['Blessed Bernard calls the union between the soul and the body "the inborn union," which is similar to the union between the form and the matter. Yet (...) properly speaking, [in that union] the act is not united to matter, but the natural act is united to a complete body in its natural form, and that form is called "the corporeal form." Thus, [the soul] has its own mode of union, and Blessed Bernard calls this union with its proper name: "the inborn union."'] See Bernard of Clairvaux, De consideratione ad Eugenium 5, c. 8 (PL 182:799C-D).

42 Bonaventure, Commentaria in III Sententiarum, d. 6, ar. 2, q. 2 (Quaracchi: Collegium S. Bonaventurae, 1887), vol. 3, pp. $160-61$. 